\title{
Manganese toxicity in Portuguese Cambisols derived from granitic rocks: causes, limitations of soil analyses and possible solutions
}

\section{Toxicidade de manganês nos Cambissolos derivados de rochas graníticas em Portugal: causas, limitações das análises de solo e soluções possíveis}

\author{
Mário Carvalho ${ }^{1^{*}}$, Michael J. Goss² and Dora Teixeira ${ }^{3}$ \\ ${ }^{1}$ Universidade de Évora, Instituto de Ciências Agrárias e Ambientais Mediterrânicas (ICAAM), Largo dos Colegiais, 7000 Évora, Portugal, \\ e-mail:* mic@uevora.pt, author for correspondence \\ 2 University of Guelph, School of Environmental Sciences, e-mail: mgoss@uoguelph.ca \\ 3 Universidade de Évora, Laboratório HERCULES, Largo dos Colegiais, 7000 Évora, Portugal, e-mail: dmt@uevora.pt,
}

http://dx.doi.org/10.19084/RCA15137

Recebido/Received: 2015.09.24

Aceite/Accepted: 2015.10.15

\begin{abstract}
A B S T R A C T
Cambisols are the major Reference Soil Group in Portugal. The yield of annual crops in these soils is generally poor, and the situation is aggravated in wet winters. In the south of Portugal, manganese toxicity has been identified as the major cause of poor growth and leaching as the main reason for the negative effect of rainfall observed in Cambisols developed on granitic formations. Manganese toxicity also appears to be present in the Cambisols in other regions of Portugal. Manganese toxicity is cross-related to the magnesium concentration, either in the soil solution or in plant shoots. Therefore, soil amendment using dolomitic limestone is needed to overcome the problem. Current soil test methods are unable to predict the level of Mn toxicity. However, new approach using the extraction of soil solution is proposed, although further work is needed to fully implement the method.
\end{abstract}

Keywords: leaching, magnesium, $\mathrm{Mg} / \mathrm{Mn}$ ratio, Soil, soil amendment

\begin{abstract}
R E S U M O
Os Cambissolos são o Grupo de Referência de Solos mais representativo em Portugal. As produções das culturas anuais são geralmente baixas e a situação agrava-se em anos de Inverno húmido. A toxicidade de manganês foi identificada como a principal causa das produções baixas e a lixiviação o principal efeito negativo dos Invernos húmidos nos Cambissolos derivados de granito no Sul de Portugal. A toxicidade de Mn está relacionada com um desequilíbrio com o magnésio, quer na solução do solo quer na concentração dos dois iões na parte aérea da planta. A solução do problema exige, assim, a aplicação de calcário dolomítico. Os actuais métodos de análise de solo não parecem capazes de prever a ocorrência da toxicidade de manganês. Uma nova abordagem utilizando a extracção da solução do solo é proposta. No entanto, a utilização desta abordagem exige investigação suplementar. A toxicidade de Mn pode não ser restrita aos Cambissolos do sul do país.
\end{abstract}

Palavras-chave: lixiviação, magnésio, razão $\mathrm{Mg} / \mathrm{Mn}$, Solo, correcção do solo

\section{Introduction}

The WRB Reference Soil Group Cambisols (WRB, 2006), mostly derived from granites, quartz-diorites and sandstones, occurs in large areas in Portugal. Cambisols developed on granites, designated by
$\mathrm{Pg}$ and Pgm in the Portuguese Soil Classification (Cardoso, 1974), are generally characterized by their coarse texture (mostly sandy loam), small cation exchange capacity (CEC) (around 5 cmolc per $\mathrm{kg}$ of 
soil), organic matter content $(\leq 1 \%)$ and water holding capacity, and strong acidity $(\mathrm{pH} \leq 5.5$ in water); extractable $\mathrm{P}$ is mostly less than $15 \mathrm{mg} \mathrm{kg}^{-1}$, and exchangeable $\mathrm{K}$ is between 0.15 and 0.25 cmolc $\mathrm{kg}^{-1}$.

The most significant agricultural system practiced on these soils is the agro-forestry-pastoral Montado system. The most important trees present in the system are the holm oak (Quercus rotundifolia Lam.) and the cork oak (Quercus suber L.). Both provide fruit for animal feed during the winter and the latter yields cork. Animal production is an important component of the Montado system, being based on temporary or permanent pastures and annual forages (usual cereals). Typical yields of these crops are poor and there is a significant and negative relationship between the production of the annual crop, wheat (Trititcum aestivum L.), and winter rainfall, which is an unexpected result given the small water holding capacity of these soils (Carvalho, 1987). In contrast, this same relationship has a positive value for soils with vertic properties

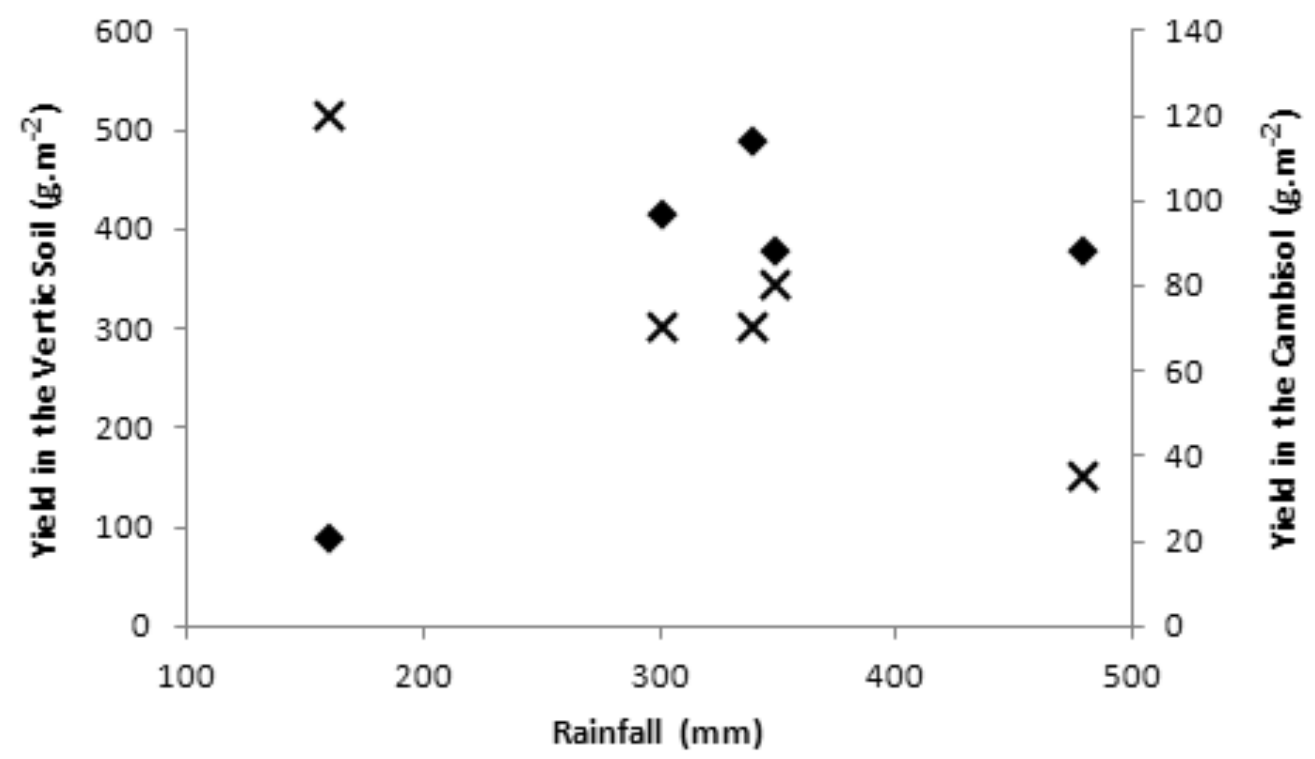

Figure 1 - Relationship between winter rainfall (from 1 of November to 28 of February) and the wheat grain yield in two different soils in the South of Portugal (Goss and Carvalho, 1988). Crosses - Cambisol; diamonds -soil with vertic properties.

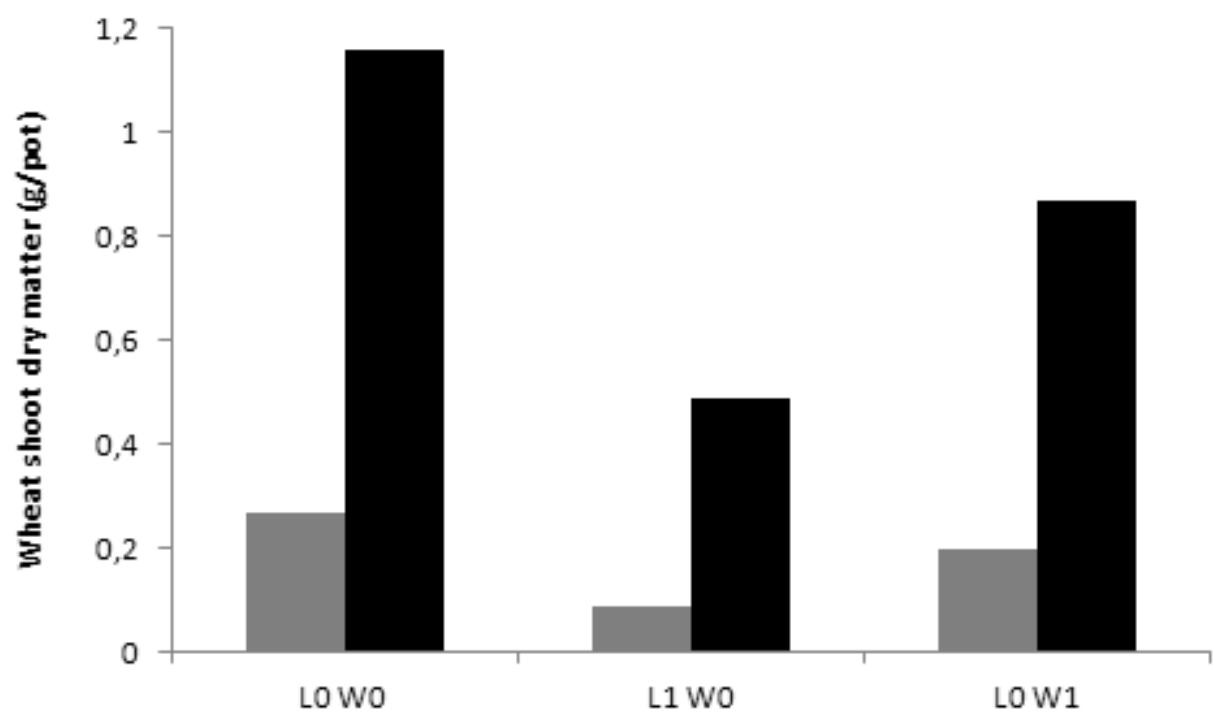

Figure 2 - Effect of leaching and waterlogging on the growth of the wheat in a Cambisol from Mitra Farm, Évora. Grey bars soil collected outside the influence of a holm oak tree; black bars - soil collected under the canopy of the tree. $\mathrm{L}$ stands for leaching and $\mathrm{W}$ for waterlogging and 0 stands for without and 1 stands for with the respective treatment. Adapted from Carvalho (1987). 
of the region, which have a much smaller saturated hydraulic conductivity (Figure 1). The negative effect of winter rainfall on the growth of the wheat in the Cambisol is more related to leaching than waterlogging, with the growth of the crop being greater under any soil water regime influenced by the tree canopy (Q. rotundifolia in the example; see Figure 2). Outside the influence of the trees, the values of soil $\mathrm{pH}$, organic matter and magnesium contents are less but extractable $\mathrm{Mn}$ is greater (Table 1). The growth of the plants was significantly and negatively correlated with the Mn concentration in important factor limiting plant growth on acid and waterlogged soils. The prediction of Mn toxicity is very complex and the specification of a critical concentration is hardly possible (Horst, 1988). The solubility of Mn is greatly affected by the $\mathrm{pH}$ (Leeper, 1970) that can rapidly change in the soil with a low CEC due to mineralization of organic matter and release of root exudates. Carvalho (1987) recorded a reduction of the $\mathrm{pH}$ (in water) of a Cambisol in the South of Portugal from 5.5 during the summer to 4.5 in November. The redox potential of the soil, which can rapidly change under field conditions,

Table 1 - Influence of holm oak (Quercus rotundifolia Lam.) on some properties of the Cambisols

\begin{tabular}{lcccc}
\hline $\begin{array}{l}\text { Position of soil } \\
\text { sample in relation }\end{array}$ & $\begin{array}{c}\mathrm{pH} \\
(1: 2 \text { soil:water })\end{array}$ & $\begin{array}{c}\text { Organic matter } \\
\left(\mathrm{g} \mathrm{kg}^{-1}\right)\end{array}$ & $\begin{array}{c}\text { Ammonium acetate extractable } \\
\left(\mathrm{mg} \mathrm{kg}^{-1}\right)\end{array}$ \\
\cline { 4 - 5 } & & & $\mathrm{Mg}$ & $\mathrm{Mn}$ \\
\hline to the tree & 4.75 & 10 & 10.6 & 32.58 \\
\hline Out of the canopy & 5.92 & 19 & 50.3 & 19.85 \\
\hline
\end{tabular}

the shoots (Figure 3). However, the negative effect of leaching was not related to any change of soil $\mathrm{pH}$ (Table 2) although leaching increased the Mn and reduced the $\mathrm{Mg}$ concentration in the shoots of the wheat (Figure 4).

Manganese toxicity has long been recognized as an also affects the solubility of Mn (Ponnamperuma, 1984). Plants may differ considerably within and between species in manganese tolerance due both to genetic characteristics and environmental factors such as nutrient availability in the soil. For example, the presence of other ions such as $\mathrm{Fe}^{2+}, \mathrm{Ca}^{2+}$ and $\mathrm{Mg}^{2+}$ can modify the uptake of manganese from

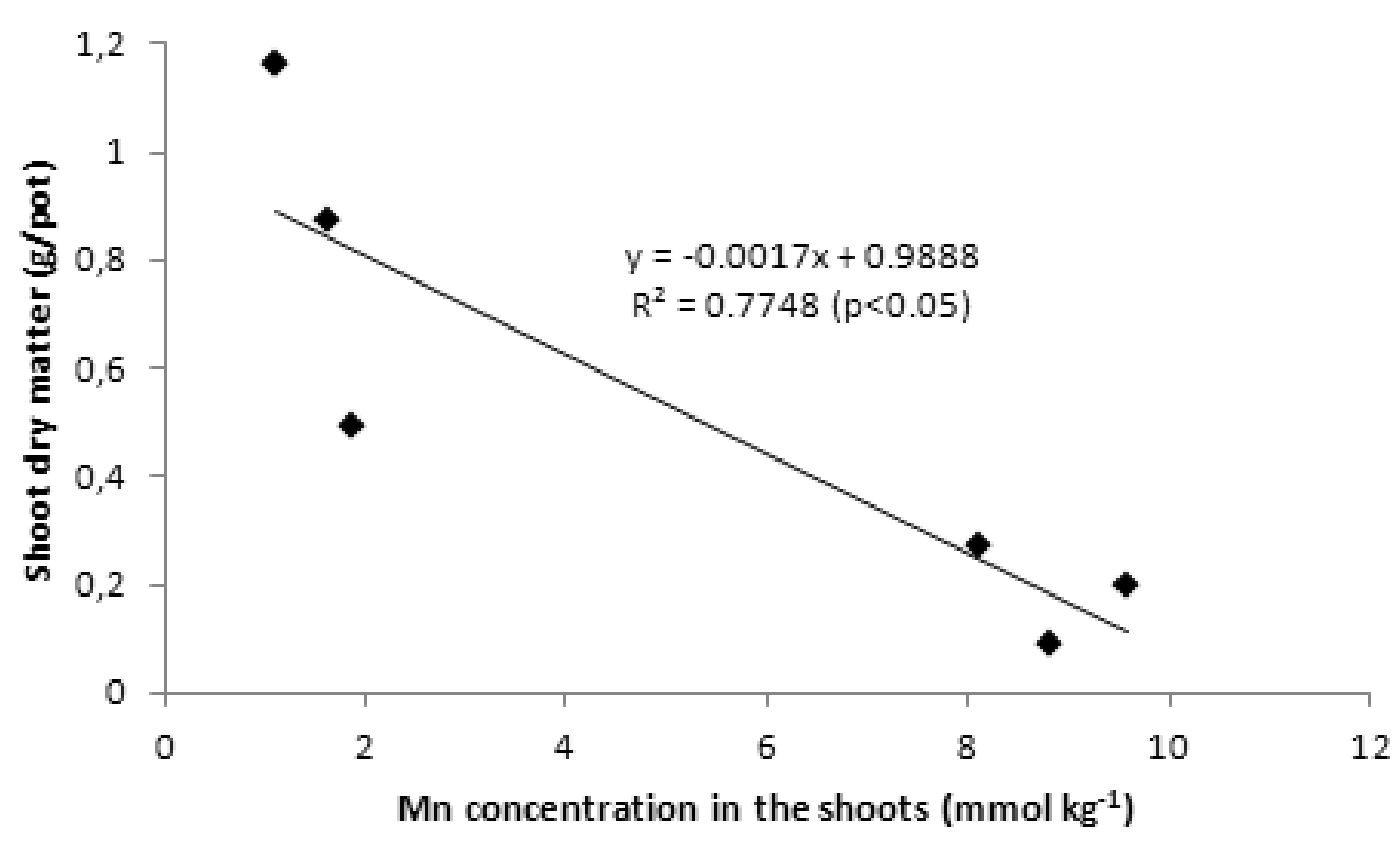

Figure 3 - Relationship between wheat growth and the Mn concentration in the shoots of the plants, for the experiment referred in the previous figure. Adapted from Carvalho (1987) 
Table 2 - Effect of leaching on the pH of the Cambisol. Leaching was promoted with distilled water with a pH of 6.4. T1, T2 and T3 stands for 1, 2 and 3 days after the starting of the leaching (Adapted from Carvalho, 1987)

\begin{tabular}{|c|c|c|c|c|}
\hline \multirow{3}{*}{ Sampling time } & \multicolumn{4}{|c|}{ Position of soil sample in relation to the tree } \\
\hline & \multicolumn{2}{|c|}{ Soil pH (1:2 soil:water) } & \multicolumn{2}{|c|}{ Drainage water $\mathrm{pH}$} \\
\hline & $\begin{array}{l}\text { Under the } \\
\text { canopy }\end{array}$ & $\begin{array}{c}\text { Out of the } \\
\text { canopy }\end{array}$ & $\begin{array}{c}\text { Under the } \\
\text { canopy }\end{array}$ & $\begin{array}{c}\text { Out of the } \\
\text { canopy }\end{array}$ \\
\hline T0 (before leaching) & 6.1 & 5.5 & - & - \\
\hline $\mathrm{T} 1$ & 6.2 & 5.5 & 7.3 & 7.3 \\
\hline $\mathrm{T} 2$ & 6.1 & 5.4 & 7.6 & 6.6 \\
\hline $\mathrm{T} 3$ & 6.1 & 5.5 & 7.6 & 6.6 \\
\hline
\end{tabular}

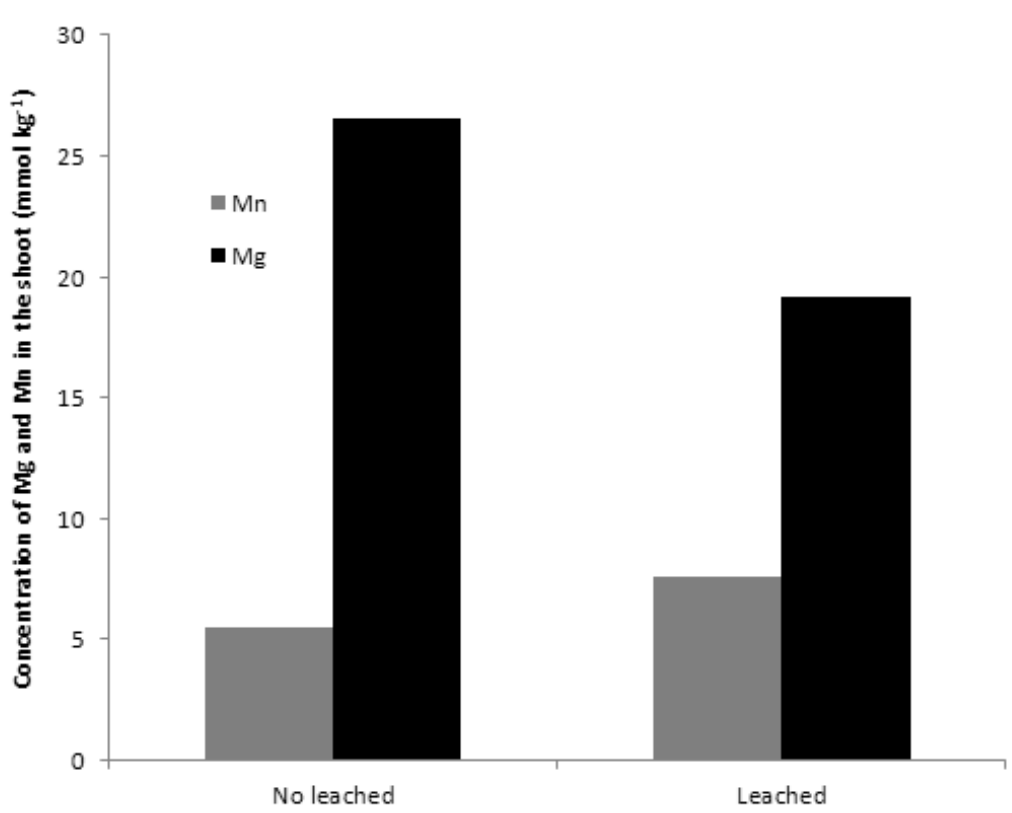

Figure 4 - Effect of leaching the soil on the concentration of magnesium and manganese in the shoots of the wheat.

solution (Löhnis, 1960; Chinnery and Harding, 1980). Within the plant, Horst and Marschner (1978) showed that expression of toxicity symptoms at a given concentration of manganese depended on the silicon content of the old leaves of Phaseolus vulgaris L.

\section{The significance of $\mathrm{Mg}$ to the Mn toxicity}

The role of Mn toxicity and the possible implication of effects on $\mathrm{Mg}$ in the poor growth of the wheat on the Cambisol in areas away from the influence of trees were investigated in a controlled environment experiment using containers, $7 \mathrm{~cm}$ internal diameter and $30 \mathrm{~cm}$ deep. The treatments were soil leaching (2 levels: with a bed volume of glass-distilled water or without), application of lime (2 levels: 0 and $2 \mathrm{~g}$ of $\mathrm{CaCO}_{3} \mathrm{~kg}^{-1}$ of dry soil) and application of $\mathrm{Mg}$ (2 levels: 0 and half a bed volume of a solution containing $1.5 \mathrm{mM}$ magnesium as $\mathrm{MgSO}_{4}$ ). Three pre-germinated seeds of T. aestioum cv. Mara were sown in each column and allow to growth for three weeks. For more detailed information on experimental procedures see Goss and Carvalho (1992). There was no unique relationship between growth of the wheat and the concentration of manganese in the shoots (Figure 5). An empirical curve could be fitted to results for plants grown in soil unamended with calcium carbonate. However, in the limed soil a wide range of plant growth was observed without any major variation of $\mathrm{Mn}$ content in shoot tissue. Nevertheless, when growth (Y) was expressed as a function of the ratio of magnesium 
to manganese concentrations in the tissue (Rp), a relationship of the form $\mathrm{Y}=\mathrm{A}+\mathrm{B} \mathrm{e}^{-\mathrm{kRp}}$ accounted for $89 \%$ of the variance (Figure 6). The relationship indicated that growth was significantly reduced when the ratio of magnesium and manganese fell below 20:1 on a weight basis or 45.8 on a molar basis. Although liming reduced manganese in shoot tissue, the plants grown on soil amended with lime had less magnesium than those from the comparable treatments on the unamended soil.
Consequently liming did not necessarily increase the ratio of the two ions in the shoots. In fact, using the same treatments in a pot experiment, Teixeira (1997) found that the application of $\mathrm{CaCO}_{3}$ to the soil reduced both the concentration of $\mathrm{Mg}$ and $\mathrm{Mn}$ in the soil solution resulting only in a marginal increase of the ratio of the two ions in soil solution (Figure 7). It is a matter of speculation why $\mathrm{Mg}$ is affecting plant tolerance to excessive levels of $\mathrm{Mn}$. The ratio of $\mathrm{Mg} / \mathrm{Mn}$ in plant cells may affect

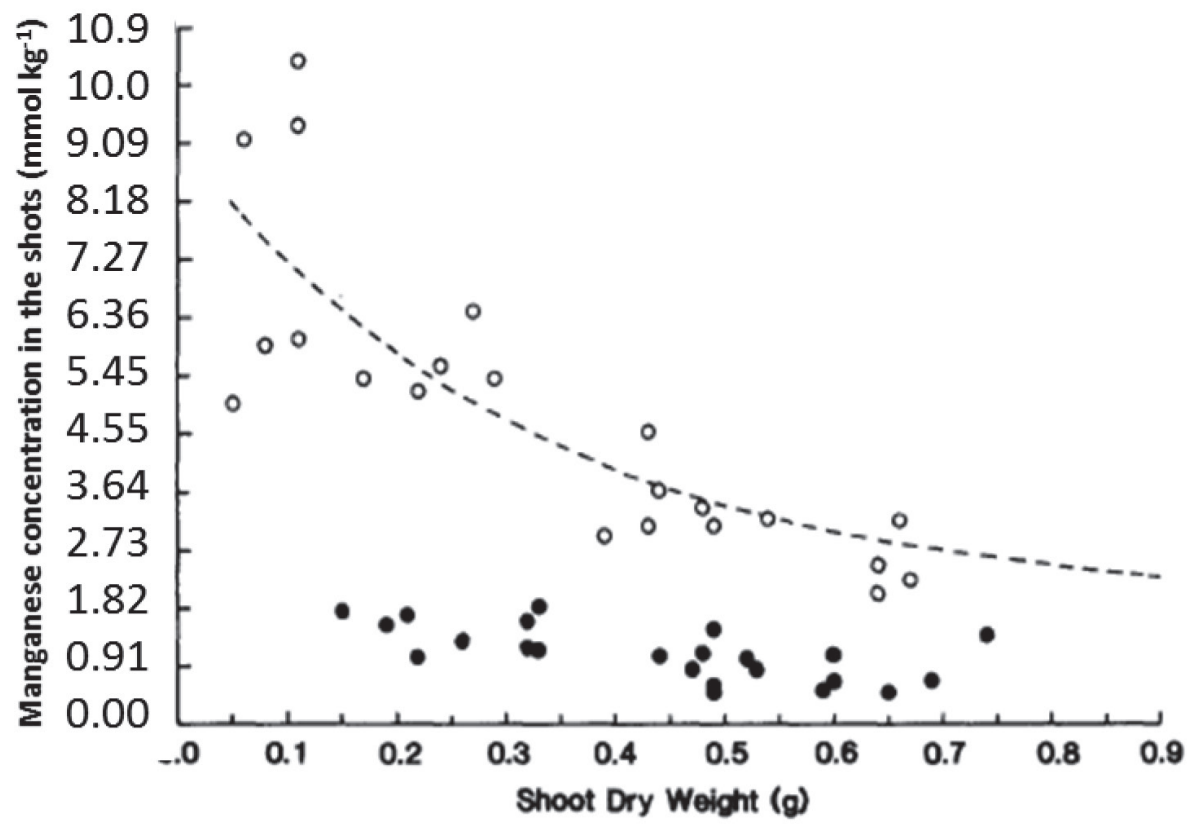

Figure 5 - Relationship between manganese concentration in the leaves of wheat plants cv Mara grown in acid soil and shoot dry weight per pot. The curve was fitted to results for soil not amended with calcium carbonate (0). Results for soil amended with calcium carbonate $(\bullet)$. Adapted from Goss and Carvalho (1992).

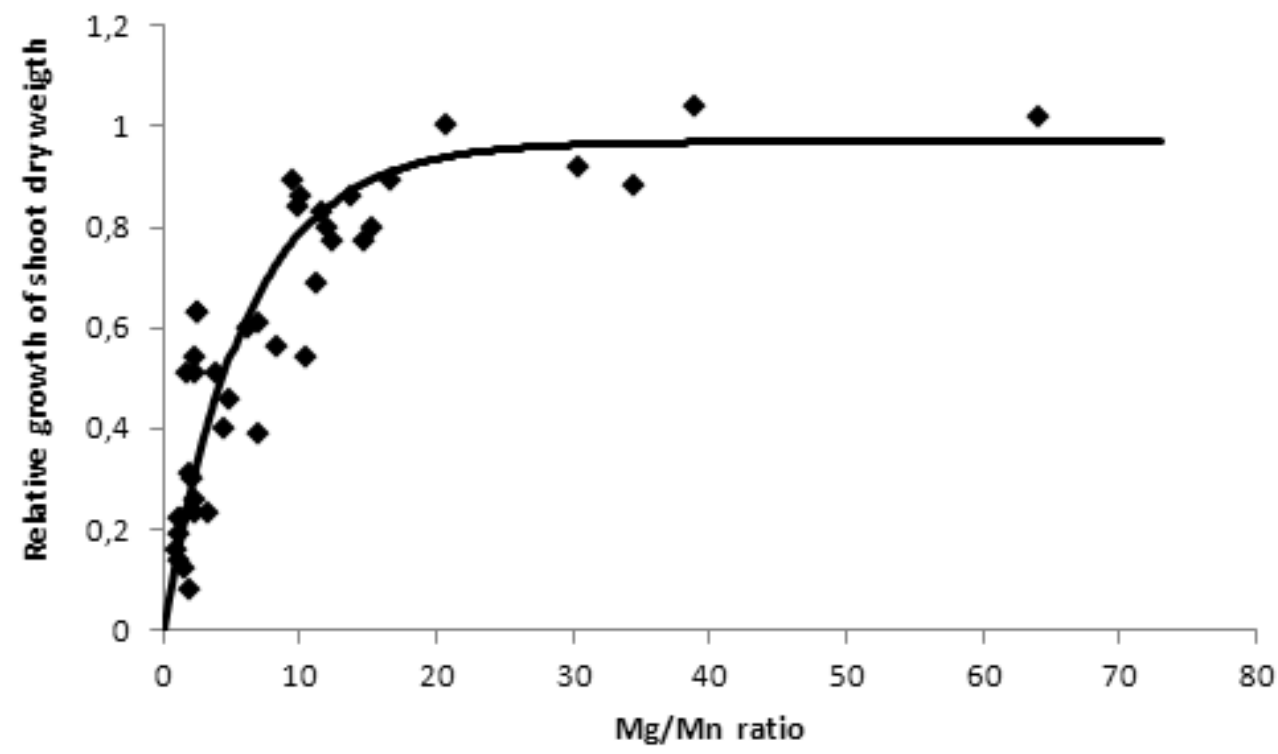

Figure 6 - Relationship between shoot growth (relative to the dry weight of the heaviest plant grown) and the Mg:Mn ratio in the leaves (weight basis). Adapted from Goss and Carvalho (1992). 


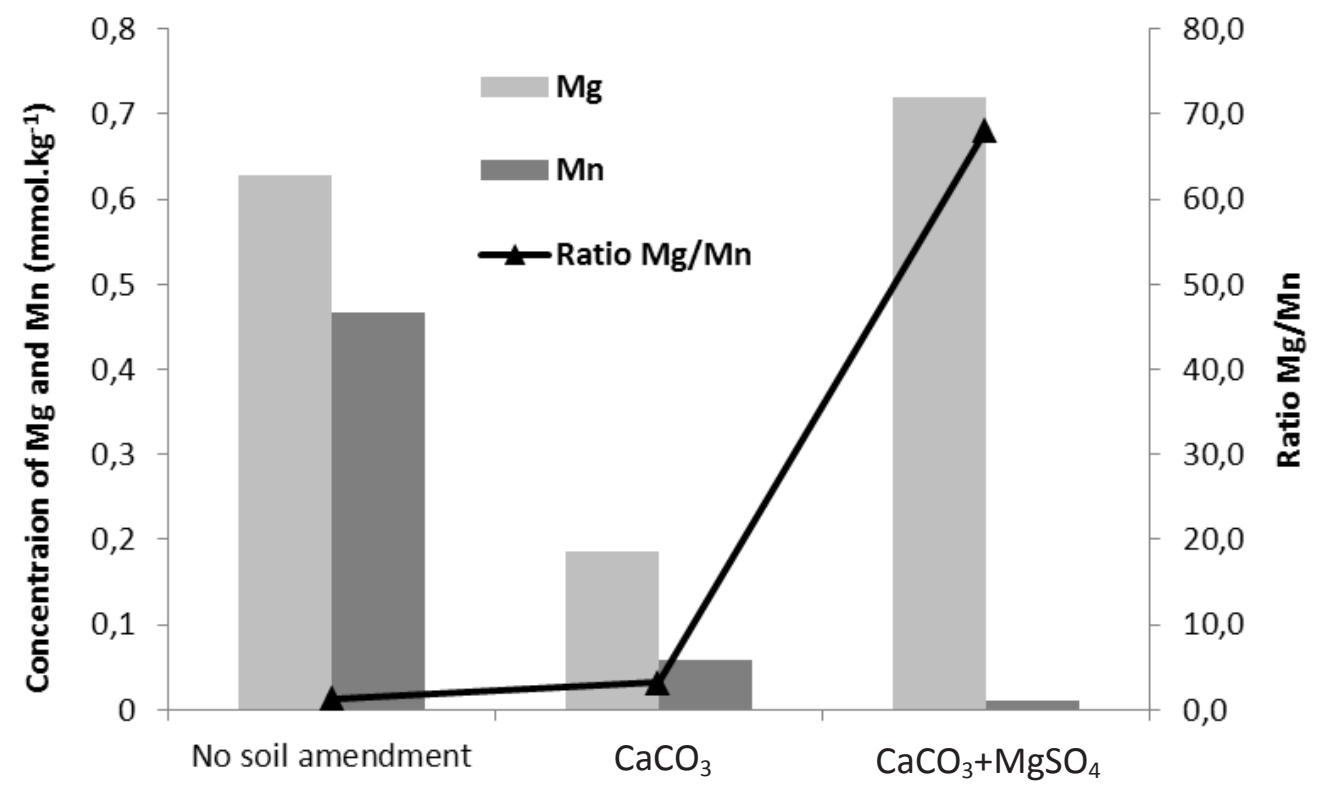

Figure 7 - Effect of soil amendment on the concentration of $\mathrm{Mg}, \mathrm{Mn}$ and the ratio of the two ions in the soil solution. Adapted from Teixeira (1997).

intracellular Mn distribution. When the ratio is high, $\mathrm{Mg}^{2+}$ may replace $\mathrm{Mn}^{2+}$ from physiologically active sites in the cytoplasm and $\mathrm{Mn}^{2+}$ may be sequestered in cell walls and vacuoles (Le Bot et al., 1990).

To understand the relationship between the concentration on $\mathrm{Mg}$ and $\mathrm{Mn}$ in the soil solution, the absorption of the two ions by the wheat plants and the level of Mn toxicity, was investigated in a solution culture experiment using 4 concentrations of $\mathrm{Mg}$ and 6 of $\mathrm{Mn}$ in factorial combination (Table 3). For more details of the experiment see Goss and Carvalho (1992). The maximum concentration of manganese in the shoots of the wheat decreased with an increasing concentration of magnesium in the nutrient solution (Figure 8). This effect is, at least, partially due a reduction in the proportion of manganese translocated from the roots to the shoots, when the concentration of magnesium increases (Figure 9). According to Marschner (1986), $\mathrm{Mn}^{2+}$ not only competes more effectively but also blocks binding sites for $\mathrm{Mg}^{2+}$ uptake. Therefore, the relative concentration of the two ions in the solution might affect both the uptake by the plant and the translocation to the shoots. This competition between the two ions was also observed in chestnut (Castanea sativa Mill.) growing in the north of Portugal in soils derived from Mnrich schists and greywackes of the Ordovician and the Silurian (Portela et al., 2011). Limitations of soil analyses

Table 3 - Concentration of $\mathrm{Mn}$ and $\mathrm{Mn}$ use in the solution culture experiment

\begin{tabular}{|c|c|c|c|c|c|c|}
\hline Element & & & ntration & lution (1 & & \\
\hline Manganese & 0.004 & 0.050 & 0.251 & 0.909 & 1.820 & 3.640 \\
\hline Magnesium & 0.015 & 0.152 & 1.517 & 15.183 & - & - \\
\hline
\end{tabular}




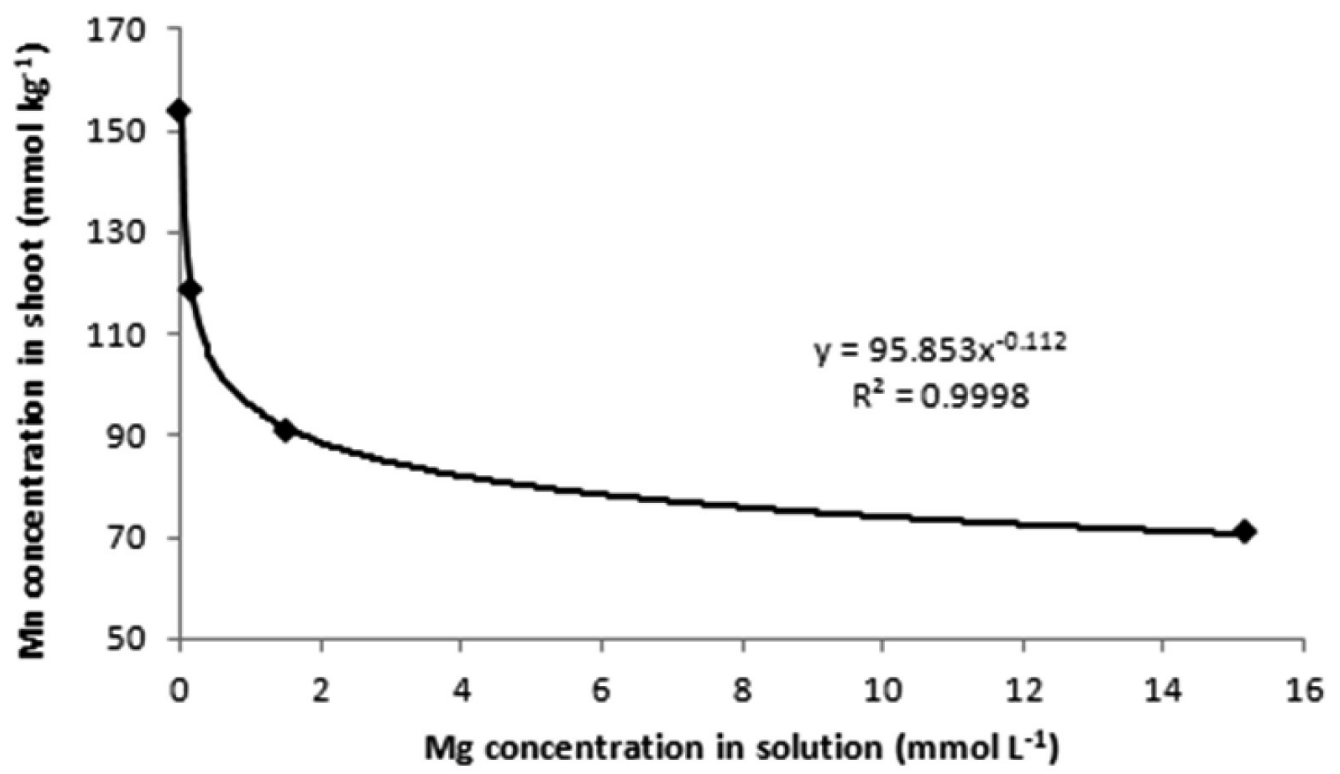

Figure 8 - The maximum concentration of manganese in shoots of the wheat as a function of the magnesium concentration in the culture solution.

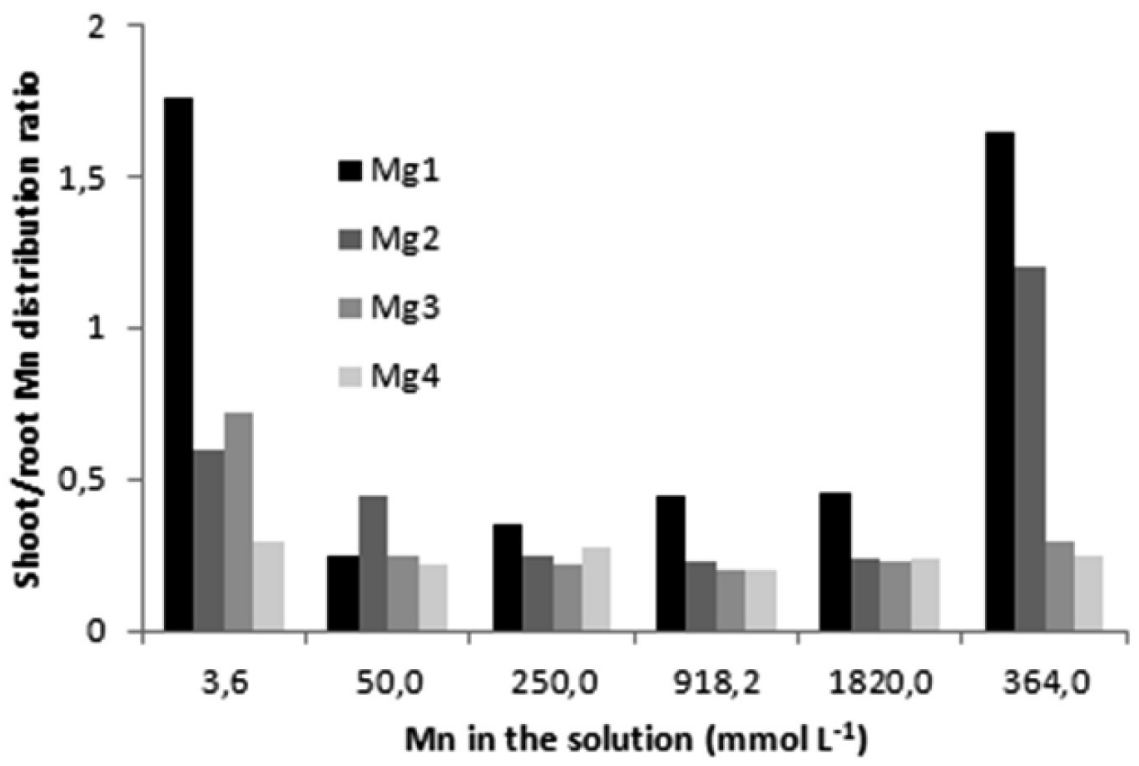

Figure 9 - Effect of the magnesium content of the culture solution on the ratio of manganese translocated to the shoots to that remaining in the roots after 3 weeks growth in 6 different concentrations of manganese. Mg1- $0.36 \mathrm{mg} \mathrm{L}^{-1} ; \mathrm{Mg}^{2}$ - $3.64 \mathrm{mg} \mathrm{L}^{-1} ; \mathrm{Mg} 3-36.4 \mathrm{mg} \mathrm{L}^{-1} ; \mathrm{Mg}^{-}-364.4 \mathrm{mg} \mathrm{L}^{-1}$.

To investigate the possibility of using soil analyses to predict manganese toxicity in the Cambisol used in the experiments referred above, different extraction methods were tested (Table 4). The detailed information of the extraction procedures are referred in Teixeira (1997). The differences in the magnesium and manganese concentration in the soil, as well the ratio of the two ions, given by the different extraction conditions were considerable (Table 5). To compare the values of these parameters in the soil with the respective concentrations in the shoot, wheat plants were grown for four weeks in a pot experiment (1.5 kg of soil per pot). N, P and $\mathrm{K}$ were added to the soil at wheat planting (18 $\mathrm{mg}$ of $\mathrm{NH}_{3} \mathrm{NO}_{3}$ and $7 \mathrm{mg}$ of $\mathrm{KH}_{2} \mathrm{PO}_{4}$ per pot). The relationship of the concentration of the two ions in the soil to that in the plant was very poor (data not shown). In Table 6 the significant regressions obtained between the ratio of the two ions in the soil and in the shoots are identified. The coefficients of determination were very poor and the best result was obtained by extracting with $\mathrm{KCl} 1.0 \mathrm{~mol} \mathrm{~L}^{-1}$ 
(extraction time 24 hours) with $\mathrm{r}^{2}=35 \%$. However, for most of the situations the values for $r^{2}$ were below 20\%. Cleary, none of the studied methods seems appropriate to predict Mn toxicity in this soil type.

Goss et al (1992), combining data from pot and solution culture experiments (Figure 10), fitted a single linear regression, that accounted for $93.8 \%$ of the variance of the natural logarithm of the ratio of the two ions (on a weight basis) both in the soil solution around the root system or in the solution culture (Rs) and in the plants (Rp):

$\ln \operatorname{Rp}=0.42( \pm 0.046)+0.48( \pm 0.013) \ln$ Rs.

Therefore, an alternative method to predict manganese toxicity would be to extract the soil solution and directly measure the concentration of the two ions. Teixeira (1997), using this approach, was able to predict the ratio of the concentration of two ions in wheat from the ratio in the soil solution after two weeks growth $(\mathrm{Rp}=0.44 \mathrm{Rs}+2.5)$ and the equation accounted for $99 \%$ of the variation. However the method needs further developments. On one hand, it will be necessary to investigate the relationship between $\mathrm{Rp}$ and Rs for different plant species and their critical $\mathrm{Rp}$ value. On the other hand, the values of Rs are changing with the growth of the crop (Figure 11). This effect of plant growth on the Rs of the soil solution might depend on the plant species and the soil, especially the cation exchange capacity. Discussion and conclusions

Manganese toxicity might be a major limitation for

Table 4 - Different extraction conditions investigate to quantify the magnesium and manganese in a Cambisol derived from granite (Teixeira, 1997)

\begin{tabular}{|c|c|c|}
\hline Extractant solution & Concentration & Time of extraction (h) \\
\hline $\mathrm{CaCl}_{2}$ & $0.01,0.1$ and $1.0 \mathrm{~mol} \mathrm{~L}^{-1}$ & 1,24 and 48 \\
\hline $\mathrm{KCl}$ & $0.1,1.0$, and $3.0 \mathrm{~mol} . \mathrm{L}^{-1}$ & 1,24 and 48 \\
\hline $\mathrm{H}_{3} \mathrm{PO}_{4}$ & $0.033 \mathrm{~mol} \mathrm{~L}^{-1}$ & 1,24 and 48 \\
\hline $\mathrm{NH}_{4} \mathrm{CH}_{3} \mathrm{COO}$ & 1.0 mol. L-1 at $\mathrm{pH} \mathrm{4,} 7$ and 9 & 1,24 and 48 \\
\hline $\mathrm{H}_{2} \mathrm{O}$ bi-distilled & - & 1,24 and 48 \\
\hline $\mathrm{H}_{2} \mathrm{O}+\mathrm{HNO}_{3}$ & $\begin{array}{c}1 \text { and } 2 \mathrm{ml} \text { of } \mathrm{HNO}_{3} \text { in } 125 \\
\mathrm{~mL} \text { of solution }\end{array}$ & 1,24 and 48 \\
\hline $\begin{array}{l}\text { DTPA (Lindsay and Norvel, } \\
\text { 1978) }\end{array}$ & $\begin{array}{c}0.005 \text { mol. } \mathrm{L}^{-1} \mathrm{DTPA}+0.1 \\
\text { mol. } \mathrm{L}^{-1} \mathrm{TEA}^{1}+0.01 \mathrm{M} \\
\mathrm{CaCl}_{2}(\mathrm{pH} 7.3)\end{array}$ & 1,24 and 48 \\
\hline
\end{tabular}

${ }_{1}$ TEA - Triethanolamine

Table 5 - Effect of the extraction conditions on the $\mathrm{Mg}$ ( $\mathrm{mmol} \mathrm{kg}^{-1}$ of soil), $\mathrm{Mn}$ ( $\mathrm{mmol} \mathrm{kg}^{-1}$ of soil) and the ratio of the concentration of the two ions in the soil. Adapted from Teixeira (1997)

\begin{tabular}{lcccccc}
\hline \multirow{2}{*}{$\begin{array}{l}\text { Extractant } \\
\text { solution }\end{array}$} & \multicolumn{2}{c}{$\mathrm{Mg}$} & \multicolumn{2}{c}{$\mathrm{Mn}$} & \multicolumn{2}{c}{$\mathrm{Mg} / \mathrm{Mn}$} \\
\cline { 2 - 7 } & Min. & Max. & Min. & Max. & Min. & Max. \\
\hline $\mathrm{CaCl}_{2}$ & 0.469 & 4.806 & 0.076 & 0.203 & 1.29 & 13.20 \\
$\mathrm{KCl}$ & 0.348 & 17.043 & 0.077 & 0.332 & 1.37 & 24.39 \\
$\mathrm{H}_{3} \mathrm{PO}_{4}$ & 0.625 & 1.590 & 0.446 & 2.299 & 0.23 & 0.62 \\
$\mathrm{NH}_{4} \mathrm{CH}_{3} \mathrm{COO}$ & 0.139 & 0.642 & 0.016 & 0.625 & 0.43 & 14.76 \\
$\mathrm{H}_{2} \mathrm{O}$ bi-distilled & 0.248 & 0.405 & Not deter. & Not deter. & Not deter. & Not deter. \\
$\mathrm{H}_{2} \mathrm{O}+\mathrm{HNO}_{3}$ & 0.421 & 0.546 & 0.097 & 0.969 & 0.24 & 1.75 \\
DTPA & 0.379 & 0.442 & 0.029 & 0.193 & 0.99 & 6.15 \\
\hline
\end{tabular}


Table 6 - Relationship between the $\mathrm{Mg} / \mathrm{Mn}$ ratio of the concentration of the two ions in the soil for the studied extraction condition and the $\mathrm{Mg} / \mathrm{Mn}$ ratio of the concentration in the shoots of 4 weeks old wheat plants. In both cases the ratios are in a weight base. Only statistically significant $(p<0.05)$ are presented (Teixeira, 1997)

\begin{tabular}{lccc}
\hline Extratant solution & Stirring time (h) & Regression & $\mathrm{r}^{2}$ \\
\hline $\mathrm{CaCl}_{2} 0.01 \mathrm{~mol} \mathrm{~L}^{-1}$ & 1 & $\mathrm{Y}=0.96 \mathrm{X}$ & 0.25 \\
$\mathrm{CaCl}_{2} 1.0 \mathrm{~mol}^{-1}$ & 1 & $\mathrm{Y}=0.36 \mathrm{X}$ & 0.17 \\
& 24 & $\mathrm{Y}=0.09 \mathrm{X}+0.84$ & 0.03 \\
$\mathrm{KCl} \mathrm{1.0} \mathrm{mol} \mathrm{L}$ & $\mathrm{Y}=0.96 \mathrm{X}$ & 0.35 \\
& 24 & $\mathrm{Y}=1.44 \mathrm{X}$ & 0.07 \\
${\mathrm{KCl} 3.0 \mathrm{~mol} \mathrm{~L}^{-1}}^{4}$ & 48 & $\mathrm{Y}=0.09 \mathrm{X}$ & 0.13 \\
$\mathrm{NH}_{4} \mathrm{CH}_{3} \mathrm{COO} \mathrm{1.0}$ & 1 & $\mathrm{Y}=0.01 \mathrm{X}+1.85$ & 0.02 \\
$\mathrm{~mol} \mathrm{~L}^{-1}$ at pH 4 & 48 & $\mathrm{Y}=4.23 \mathrm{X}+0.08$ & 0.12 \\
$\mathrm{NH}_{4} \mathrm{CH}_{3} \mathrm{COO} 1.0$ & 24 & $\mathrm{Y}=0.38 \mathrm{X}+0.46$ & 0.13 \\
$\mathrm{~mol} \mathrm{~L}^{-1}$ at pH 7 & 48 & $\mathrm{Y}=0.16 \mathrm{X}+1.27$ & 0.04 \\
$\mathrm{H}_{2} \mathrm{O}_{+} 1 \mathrm{ml} \mathrm{HNO}_{3} 0.5$ & 1 & $\mathrm{Y}=0.60 \mathrm{X}+0.83$ & 0.13 \\
$\mathrm{~mol} \mathrm{~L}^{-1}$ & 24 & $\mathrm{Y}=3.45 \mathrm{X}$ & 0.24 \\
\hline
\end{tabular}

the pasture and forage production in the Montado system in Cambisols derived from granites in the south of Portugal, although the problem might also affect Cambisols derived from other rocks and in other regions of the country. The Mn toxicity is related to the ratio of the concentration of $\mathrm{Mg} / \mathrm{Mn}$ in shoot tissue. The severity of the toxicity increases in wet winters due waterlogging and leaching, but mainly to the latter, apparently because the

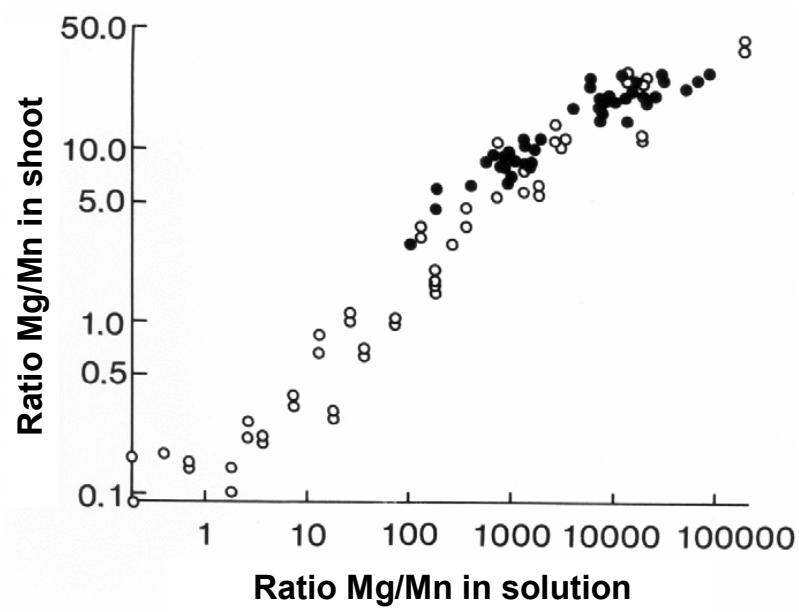

Figure 10 - Relationship between the ratio of $\mathrm{Mg}: \mathrm{Mn}$ in the solution around the root system of the wheat ant the ration in the shoot tissue (ratios are in a weight base). Full black circles - wheat grown in soil. Open circles - results from Goss and Carvalho (1992) for wheat grown in solution culture (Goss et al., 1992).
Mn concentration increases in the soil. The same effect could be detected just by growing of plants, probably due to acidification of the soil by root exudates and the use of $\mathrm{N}$ fertilizer. The prediction of the Mn toxicity using soil test methods is very difficult, as extraction procedures are not able to mimic the effects of leaching and soil acidification on the ratio of $\mathrm{Mg}$ and $\mathrm{Mn}$ in the soil solution. An alternative approach is to measure the ratio of $\mathrm{Mg} / \mathrm{Mn}$ concentrations in the soil solution and to

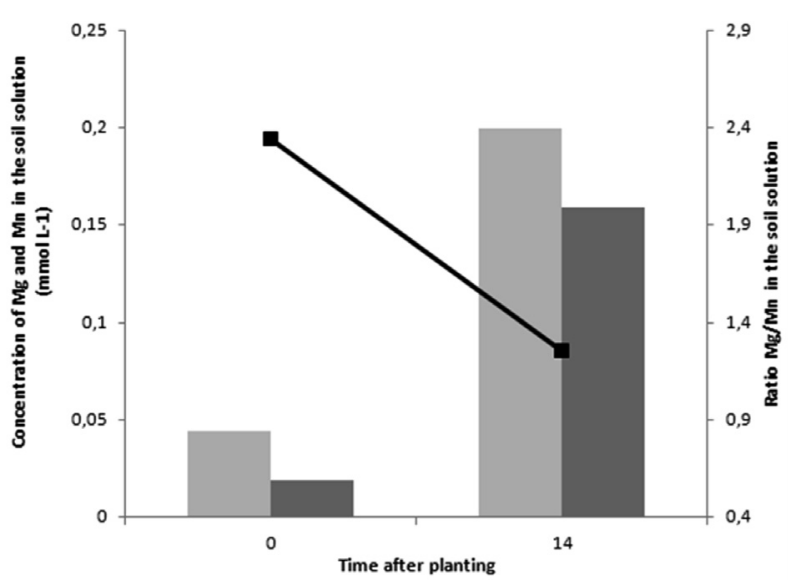

Figure 11 - Concentration of magnesium (light grey bars), manganese (dark grey bars), and the ratio $\mathrm{Mg}: \mathrm{Mn}$ (black line) in the soil solution before planting wheat and after 14 days growth. Adapted from Teixeira (1997). 
obtain an effective correlation as for the one found for wheat plants. However, further knowledge is needed, particularly the critical concentration of the two ions $\mathrm{Mg} / \mathrm{Mn}$ ratio in the cells for different plant species. In addition, we need to understand the effect of plant species on the concentration of the two ions in the soil solution and identify the best soil solution extraction procedures that mimic these effects.

Mn toxicity in the Cambisols cannot be alleviated by the addition of $\mathrm{CaCO} 3$, because $\mathrm{Ca}$ depressed both the $\mathrm{Mg}$ and the $\mathrm{Mn}$ present in soil solution and, therefore, had only a marginal effect on the ratio between the two ions. Magnesium has to be added simultaneously to complete remove the stress and the application of dolomitic limestone is the obvious solution. Because of the real difficulty in predicting manganese toxicity in Portuguese Cambisols based on soil analyses, we need to understand how pedogenetic processes, together with the nature of the parent material, influence the severity of the problem. We could then establish how the magnitude of the problem varies across the country and thereby advise farmers.

\section{References}

Cardoso, J.V.C. (1974) - A classificação dos solos de Portugal - Nova versão. Boletim de Solos do S.R.O.A., n. 17, p. 14-46.

Carvalho, M. (1987) - Factores limitantes e técnicas culturais da produção de trigo mole no Alentejo. Tese de doutoramento. Évora, Universidade de Évora, 214 p.

Chinnery, L.E. and Harding, C.P. (1980) - The effect of ferrous ion on the uptake of manganese by Juncus effuses. Annales of Botany, vol. 46, n. 4, p. 409-412.

Goss, M.J. and Carvalho, M. (1988) - Causes of variation in yields of wheat under dryland farming in the Alentejo region of Portugal and some future prospects. In: Unger, P.W.; Jordan, W.R. and Sneed, I.V. (Eds.) - Proceedings of the International Conference on Dryland Farming. Texas A\&M University, College Station, USA, p. 445-448.

Goss, M.J. and Carvalho, M. (1992) - Manganese toxicity: The significance of magnesium for the sensitivity of wheat plants. Plant and Soil, vol. 139, n. 1, p. 91-98. http://dx.doi.org/10.1007/BF00012846

Goss, M.J.; Carvalho, M.; Cosimini, V. and
Fearnhead, M.L. (1992) - An approach to the identification of potentially toxic concentrations of manganese in soils. Soil Use and Management, vol. 8 , n. 1, p. 40-44.

http://dx.doi.org/10.1111/j.1475-2743.1992. tb00891.x

Horst, W.J. (1988) - The physiology of manganese toxicity. In: Graham, R.D.; Hannam, R.J. and Uren, N.C. (Eds.) - Manganese in soils and plants. Dordrecht, The Netherlands, Kluwer Academic Publishers, p. 175-188.

Horst, W.J. and Marschner, H. (1978) - Effect of silicon on manganese tolerance of bean plants (Phaseolus vulgaris L.). Plant and Soil, vol. 50, n. 1, p. 287-304. http://dx.doi.org/10.1007/BF02107179

Le Bot, J.F.; Goss, M.J.; Carvalho, M.; Van Beusichem, M.L. and Kirkby, E.A. (1990) - The significance of magnesium to manganese ratio in plant tissues for growth and alleviatium of manganese toxicity in tomato (Lycopersicon esculentum) and wheat (Triticum aestivum) plants. Plant and Soil, vol. 124, n. 2, p. 205-210.

http://dx.doi.org/10.1007/BF00009261

Leeper, G.M. (1970) - Six trace elements in soils. Melbourne, Melbourne University press, $59 \mathrm{p}$.

Löhnis, M.P. (1960) - Effect of magnesium and calcium supply on the uptake of manganese by various crop plants. Plant and Soil, vol. 12, n. 4, p. 339-376. http://dx.doi.org/10.1007/BF02232990

Marschner, H. (1986) - Mineral nutrition of higher plants. London, Academic Press, 674 p.

Ponnamperuma, F.N. (1984) - Effect of flooding on soils. In: Kozowski, T.T. (Ed.) - Flooding and plant growth. London, Academic press, p. 10-45.

Portela, E.; Coelho-Pires, C. and Louzada, J. (2011) Carência de magnésio em castanheiro: Influência do manganês do solo. Revista de Ciências Agrárias, vol. 34, n. 2, p. 154-162.

Teixeira, D. (1997) - Métodos de determinação de magnésio e manganês no sistema solo-água-planta para a previsão da toxicidade de Mn num solo ácido. Tese de Mestrado. Évora, Universidade de Évora, 159 p.

WRB (2006) - World reference base for soil resources, 2nd edition. World Soil Resources Reports 103. Rome, FAO, 128 p. 